\title{
Suspension of Detention of Suspects in Framework of Realizing Human Rights Protection
}

\author{
Fitriani Akrima ${ }^{*}$ and Jawade Hafidz ${ }^{* *}$ \\ *) Master of Law, Faculty of Law, Universitas Islam Sultan Agung Semarang, E-mail: \\ fitrianiakrima96@gmail.com \\ ${ }^{* *}$ Faculty of Law, Universitas Islam Sultan Agung Semarang
}

\begin{abstract}
.
The purpose of this research is 1) To find out and analyze the detention suspension process for suspects at the Bogor Police; 2) To find out and analyze about suspended detention to realize the protection of human rights, and to find out and analyze the obstacles in the implementation of suspension of detention and efforts to overcome them. The approach method used is Sociological juridical which in other words is a type of sociological legal research and can also be called field research, which examines the applicable legal provisions and what happens in reality in society. This research was analyzed using the theory of law enforcement, human rights and justice. The conclusion of this research is that the process of detention of a suspect at the Bogor Police is given to a suspect who has committed a criminal act and is carried out by the investigator, where the suspect in a criminal case filed strong and accountable reasons a request or request for a suspension of detention which can later be used as a basis for consideration and in accordance with Article 31 of the Criminal Procedure Code it has been stated that the suspension is carried out based on stipulated conditions, namely compulsory reporting, not leaving the house or not leaving the city.
\end{abstract}

Keywords: Suspension; Detention; Suspect; Protection; Human Rights.

\section{Introduction}

Indonesia as a rule of law country has independent characteristics, which means that independence can be seen from the application of the rule of law concept or pattern it adheres to. The concept adopted by our country is adapted to the existing conditions in Indonesia, namely Pancasila. Departing from the idea that becomes the issue of justice seekers to the problem that most often becomes discourse is about the issue of justice in relation to law. According to Attamimi stated that "This is due to the law or a form of statutory regulation that is applied and accepted with different views, the view that the law is fair and vice versa the law is unfair". ${ }^{1}$

Regarding the definition of a criminal act, Halim uses the term "offense to translate strafbaarfeit, and defines it as an act or act which is prohibited and is punishable by law". ${ }^{2}$ Lamintang provides a general formulation regarding strafbaarfeit, namely "A human behavior which at a certain time has been

\footnotetext{
1 Attamimi, A. Hamid S. (2007). Ilmu Perundang-undangan, Jenis, Fungsi, dan Materi Muatan, Yogyakarta: Kanisius. p.52.

2 Halim, Ridwan A. Hukum Pidana dan Tanya Jawab, Jakarta: Ghalia Indonesia. p.31.
} 
rejected in a certain social life and is considered to be behavior that must be eliminated by criminal law by using coercive means contained therein." 3

In the framework of law enforcement in accordance with the Criminal Justice System, the National Police is tasked with conducting criminal investigations carried out by investigators / assistant investigators in the Police Criminal Investigation Function as well as Polri operational functions which are authorized to carry out investigations and coordinate and supervise Civil Servant Investigators (PPNS). According to Rahardjo stated that: "The police are at the forefront of criminal law enforcement, so it is not an exaggeration to say that the police are a living criminal law that translates and interprets law in the book into law in action"4.

Basically, detention is an act that violates human rights because detention of a person certainly reduces that person's independence or freedom. However, it needs to be realized that it is necessary to detain someone because that person has committed a criminal act. According to Hamzah said that "Detention is a form of deprivation of freedom". 5

According to Arief, it is in accordance with the presumption of innocence principle, namely "A person cannot be said to be a person who is guilty before a court decision has permanent legal force".6 Dikoro argues that:

In the State of Indonesia, it is also related to the existence of a principle of Pancasila which is Humanity, in carrying out its obligations investigators and prosecutors of criminal cases must always remember this essence and consider the suspect to always be a subject who has the full right to defend himself. ${ }^{7}$

Humanity is important but far more important is the experience of both citizens, especially law enforcement officials. Every law enforcement apparatus is obliged to uphold Humanity. According to Marpaung, he stated that "Isn't it necessary for the community to enforce the law to enforce the law where the law itself has protected the interests of the community". ${ }^{8}$

Although the Criminal Procedure Code provides guarantees for the protection of human rights, it does not mean that a suspect can easily escape the legal process even though the presumption of innocence has been adhered to. In formal law (the Criminal Procedure Code), Rukmini states that "Eliminating one's freedom is not a necessity for law enforcement officials". ${ }^{9}$

\footnotetext{
${ }^{3}$ Lamintang, P.A.F. (2016). Dasar-dasar Hukum Pidana Indonesia, Bandung: Sinar Baru. p.172.

${ }^{4}$ Rahardjo,Satjipto. (2002). Polisi Sipil dalam Perubahan Sosial di Indonesia, Jakarta: Kompas. p.115.

${ }^{5}$ Andi Hamzah. (2011). Bunga Rampai Hukum Pidana dan Acara Pidana, Ghalia Indonesia, Jakarta, p.19.

6 Arief,Barda Nawawi. (2011). Masalah Penegakan Hukum dan Kebijakan Penanggulangan Kejahatan, Bandung: PT. Citra Aditya Bakti. p.23.

7 Dikoro, Wirjono Prodjo. (2012). Hukum Acara Pidana di Indonesia, Bandung: Sumur Bandung. p.16.

8 Marpaung, Leden. (2011). Proses Penanganan Perkara Pidana (Penyelidikan dan Penyidikan), Jakarta: Bina Aksara. p.46.

9 Mien, Rukmini. (2013). Perlindungan HAM melalui Asas Praduga tidak Bersalah dan Asas Persamaan Kedudukan dalam Hukum pada Peradilan Pidana Indonesia, Bandung: PT. Alumni. p.32.
} 
Suspended detention is removing a suspect or defendant from detention before the end of his detention period. In order to ensure that a suspect or defendant who is detained is not harmed by his interests because of the detention which may last for some time, it is possible for the suspect or defendant to submit a request that his detention be suspended. The period of suspension of detention does not include the period of detention status. ${ }^{10}$

The issue of detention will remain a very interesting topic of discussion because detention is closely related to the deprivation of a person's right to freedom. In Article 1 point 21 of the Criminal Procedure Code, it is explained that a detention is the placement of a suspect or defendant in a certain place by an investigator or public prosecutor or a judge by its stipulation, in matters and according to methods regulated by law.

If a suspect or defendant has been given a suspension of detention that does not meet the conditions that have been determined, the suspension of detention can be revoked (Article 31 paragraph 2 of the Criminal Procedure Code). The elucidation of Article 31 of the Criminal Procedure Code states that detention suspension is a factor that becomes the basis for granting in PP No.27 of 1983 the existence of guarantees in the form of money or in person is regulated in Article 35 and Article 36. The main issues in suspension revolve around the issue of terms and guarantees of suspension" .11The above is reinforced by the results of research by Ibrahim on Suspension of Detention in Criminal Case Processes (Case Study of the Palu District Attorney) which explains that the suspension of detention, although the basis used is the Criminal Procedure Code as a reference for all legal officers in Indonesia, but in practice it is often good. Both the investigator and the public prosecutor shall keep a security deposit for the suspension of detention of the suspect or defendant in their respective agencies (investigation, prosecution and court). This is what makes the law in the eyes of the public less trusted because of the lack of legal certainty that should be enforced by legal officials. ${ }^{12}$

In this study, the authors identified the following research problems: 1 ) How is the process of suspending detention of suspects at the Bogor Police? 2) Can the suspension of detention realize the protection of human rights? 3) Constraints encountered in implementing suspension of detention and efforts to overcome them?

\section{Research Methods}

Sociological juridical approach method wants to see aspects of legal norms and their application in society regarding suspension of detention of the suspect in order to realize human rights protection at the Bogor Police. This research is qualitative. Research with a qualitative approach is research aimed

\footnotetext{
${ }^{10}$ Is, Muhammad Sadi. (2015). Kumpulan Hukum Acara di Indonesia, Jakarta: Prenadamedia Group. p.86.

${ }^{11}$ Djindang, Moh. Saleh. (2009). Pengantar Hukum Indonesia, Jakarta: Sinar Harapan. 2009. p.231.

12 Ibrahim. (2017). "Penangguhan Penahanan Dalam Proses Perkara Pidana (Studi Kasus Kejaksaan Negeri Palu), Legal Opinion, Palu, ISSN 2527-9505 Vol 3, No 3.
} 
at describing and analyzing phenomena, events, social activities, attitudes, beliefs, perceptions, thoughts of people individually or in groups. ${ }^{13}$ Methods of data analysis using qualitative analysis methods Analytical activities consist of three activities that occur simultaneously, namely data reduction, data presentation, and drawing conclusions / verification about implementation of suspension of detention of suspects in criminal cases at the Bogor Police.

\section{Results and Discussion}

\subsection{The Process of Suspecting the Detention of the Suspect at the Bogor Police}

The National Police as an investigator in handling child crimes is required to diversify through a restorative justice approach. The problem of this research is using the analysis knife of restorative justice theory and discretion theory. ${ }^{14}$ Criminal law is public law, so that the main objective of holding criminal law is to protect the interests of the community as a collectivity from actions that threaten or even harm them, whether they come from individuals or groups of people (an organization). ${ }^{15}$ The law stipulates what should be done and / or what can be done and what is prohibited. The target of the law to be aimed at is not only people who actually act against the law, but also legal actions that may occur, and to the state apparatus to act according to the law. This system of law operation is a form of law enforcement. Law enforcement is necessary under any circumstances, especially with the rapid development and advancement of science and technology which is followed by an increase in the crime rate. ${ }^{16}$

The integrated law enforcement system based on the Criminal Procedure Code has so far adhered to the principle of a division of function or compartment system, which clearly separates the duties and authorities of investigation, prosecution and examination in court sessions and the implementation of integrated court decisions and decisions, leading to an integrated criminal justice system, but in practice there is no synergy between related institutions. ${ }^{17}$

In the framework of forming a government that protects the entire Indonesian nation and all the blood of Indonesia, advances public welfare, educates the nation's life, and implements world order, based on independence, eternal peace and social justice, the independence of the Indonesian nation is compiled in a law. the basis of the republic of Indonesia which is formed in a

\footnotetext{
13 Nana, Syaudih Sukmadinata. (2007). Metode Penelitian, Bandung: Remaja RosdaKarya. p.60.

14 Anita Indah Setyaningrum, and Umar Ma'ruf. (2017). "Diversi Sebagai Bentuk Penyelesaian Perkara Pidana Anak Melalui Pendekatan Restorative Justice Oleh Penyidik Polda Jawa Tengah", Jurnal Hukum Khaira Ummah Vol. 12. No. 4 December 2017: 975 - 980.

15 Aluysius Sutikna, Sri Kusriyah, and Widayati. (2017). "Implementasi Undang-Undang Nomor 30 Tahun 2014 Tentang Administrasi Pemerintahan Terhadap Proses Penyidikan Tindak Pidana Korupsi Di Polres Rembang, Jurnal Hukum Khaira Ummah Vol. 13. No. 1 March 2018: 19 - 28.

16 Sapto Winengku, and Umar Ma'ruf. (2017). "Teknik Pembelian Terselubung Dalam Penyidikan Tindak Pidana Narkotika", Jurnal Hukum Khaira Ummah Vol. 12. No. 4 December 2017: 875-883.

17 Teguh Prihmono, Umar Ma'ruf, and Sri Endah Wahyuningsih. (2017). "Peran Laboratorium Forensik Polri Sebagai Pendukung Penyidikan Secara Ilmiah Dalam Sistem Peradilan Pidana Di Indonesia, Jurnal Hukum Khaira Ummah Vol. 13. No. 1 March 2018: 273-286.
} 
composition of the Republic of Indonesia with people's sovereignty, as stated in the fourth paragraph in the preamble to the 1945 Constitution, which reads "Democracy led by wisdom in deliberation / representation".18

In principle, detention was carried out to facilitate the interests of examination. With the detention of a suspect / defendant, it is clear that it will simplify and streamline the examination process if compared to if a suspect / defendant is released or not detained or there is a possibility that he will escape or escape criminal threats. In addition, detention was carried out to keep the suspect / defendant from disturbing public security and order, to remove evidence and even to avoid the possibility of repeating his actions.

The provisions of Article 31 of the Criminal Procedure Code mentioned above, then a suspension of detention can be requested by all suspects or defendants by submitting an application to the agency conducting the detention, be it the police, prosecutor's office or the court, which in this case is represented by a judge. After the application is made, the competent authority shall consider whether the request for suspension of detention from the suspect or defendant is granted or rejected.

If criminal means are called to tackle crimes, it means that criminal law politics will be implemented, namely holding elections to achieve results of criminal legislation that are in accordance with the circumstances and situations at one time and for the future.

\subsection{Suspension of Detention Can Promote Human Rights Protection}

Investigations of suspects, which are carried out by investigators (police), are often carried out with acts of violence and intimidation and other forms of coercion just to obtain information and evidence of the suspect's involvement in a case. This further proves the weak knowledge and skills of investigators on law and human rights. Constitutional guarantees for human rights are important for the direction of implementing the constitutionality of a country. The guarantee of the basic rights of every citizen means that every ruler in the state cannot and should not act arbitrarily to his citizens, even the existence of these basic rights also means that there is balance in the state, namely the balance between powers in the state and the basic rights of citizens.

Protection of the human rights of suspects is also contained in the Law on Judicial Power which is stated in several articles, especially regarding the principles of fast, simple and low cost trial as stated in Article 2 paragraph (4). The principle of non-discrimination in Article 4 Paragraph (1), the principle of presumption of innocence contained in Article 8 Paragraph (1), there are provisions for rehabilitation if there are mistakes in arrest and detention, up to the provisions of Article 56 concerning the right of suspects to obtain legal assistance.

\footnotetext{
18 Ahmad Rifa'i, and Sri Kusriyah. (2017). "Peran Partai Politik Dalam Pengawasan Terhadap Kadernya Yang Duduk Di DPRD Untuk Meningkatkan Kualitas Perwakilan", Jurnal Hukum Khaira Ummah Vol. 12. No. 4 December 2017: 981 - 992.
} 
Detention is often carried out without regard to the content of Article 21 of the Criminal Procedure Code. Especially regarding the threat of punishment, it is often ignored which ultimately causes anyone who is considered a suspect to be detained against him regardless of the length of the threat of punishment, this action will result in full detention while the facilities provided are very lacking. Detention by law enforcement officers (investigators) against a suspect will generate negative perceptions among the public.

Violation of the rights of suspects, defendants and convicted by law enforcement officers which is a sub-system of the Criminal Justice System occurs in various parts of the world and is known as miscarriage of justice. If a law enforcement official who has the power and authority to achieve justice, actually uses the power and authority at his disposal to provide injustice, that's when a miscarriage of justice occurs or failure to enforce justice.

Islam came to the face of this earth to uphold justice. So that every human being servant of Allah SWT gets this very important right to justice. Islam oblige s its people to uphold justice even for itself. This has been explicitly explained by Allah SWT in QS. 42 (ash-Shura): 15, namely:

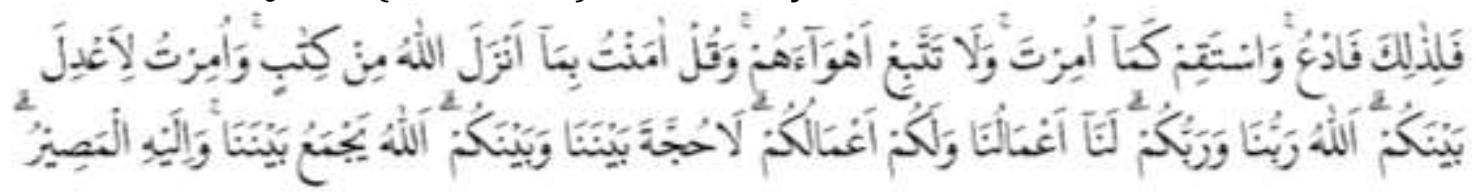

Meaning: So therefore call (them to that religion) and remain as instructed to you and do not follow their lusts and say: "I believe in all the books that Allah sent down and I am commanded to be fair among you. Allah is our Lord and your Lord. For us our deeds and for your deeds. There is no quarrel between us and you, Allah gathers between us and Him (our) return.

\subsection{Constraints in the Implementation of Suspension of Detention and Efforts to Overcome Them}

Law enforcement efforts mean that there is an effort to maintain the existence of a law that is recognized in a society to be upheld. Basically, these efforts must ensure that every citizen obeys the applicable laws in the society concerned. Law enforcement is a process to bring legal desires into reality. What is referred to as legal desires here are none other than the thoughts of a legislative body which are formulated in legal regulations so that law enforcement and lawmaking cannot be separated.

Based on the results of the research conducted by the author, it can be seen that apart from the inability of the suspect to fulfill the conditions for suspension of detention, another obstacle is due to the subjective requirements in Article 21 paragraph (1) of the Criminal Procedure Code. If a law enforcer has a concern that a suspect or defendant will run away, destroy or lose evidence and are afraid that the crime will repeat, then the official concerned has the right to use his / her authority to detain the suspect or defendant. This factor causes the number of applications for suspension of detention that have not been approved. Law enforcement is essentially a process of manifesting abstract ideas (ideas of justice, ideas of legal certainty, and ideas of social benefit) into reality. 


\section{Closing}

The process of suspending the detention of a suspect at the Bogor Police is given to a suspect who has committed a criminal act and is carried out by an investigator, where the suspect in a criminal case submits strong and accountable reasons pa request or request for a suspension of detention which can later be used as a basis for consideration and in accordance with Article 31 of the Criminal Procedure Code it has been stated that suspension is carried out based on stipulated conditions, namely compulsory reporting, not leaving the house or not leaving the city Suspension of detention can realize the protection of human rights detention that violates human rights in the form of inhuman treatment of detainees, for example torture and torture during examination to obtain information from the suspect, discriminatory treatment between prisoners. Detention is an act of law enforcement officials that is directly related to human rights, so that its implementation must be carried out based on the provisions of the criminal procedure law, namely: a) Detention can only be carried out for the purposes of investigation, prosecution and examination in court. b) Fulfills the objective requirements, namely that the suspect or defendant is strongly suspected of committing a crime punishable by five years or more or a penalty of less than five years but is directly stated by law. c) There is a concern that the suspect or defendant will run away,

\section{References}

\section{Journals:}

[1] Ahmad Rifa'i, and Sri Kusriyah. (2017). "Peran Partai Politik Dalam Pengawasan Terhadap Kadernya Yang Duduk Di DPRD Untuk Meningkatkan Kualitas Perwakilan", Jurnal Hukum Khaira Ummah Vol. 12. No. 4 December 2017: 981 - 992.

[2] Aluysius Sutikna, Sri Kusriyah, and Widayati. (2017). "Implementasi UndangUndang Nomor 30 Tahun 2014 Tentang Administrasi Pemerintahan Terhadap Proses Penyidikan Tindak Pidana Korupsi Di Polres Rembang, Jurnal Hukum Khaira Ummah Vol. 13. No. 1 March 2018: 19 - 28.

[3] Anita Indah Setyaningrum, and Umar Ma'ruf. (2017). "Diversi Sebagai Bentuk Penyelesaian Perkara Pidana Anak Melalui Pendekatan Restorative Justice Oleh Penyidik Polda Jawa Tengah", Jurnal Hukum Khaira Ummah Vol. 12. No. 4 December 2017: 975 - 980.

[4] Sapto Winengku, and Umar Ma'ruf. (2017). "Teknik Pembelian Terselubung Dalam Penyidikan Tindak Pidana Narkotika", Jurnal Hukum Khaira Ummah Vol. 12. No. 4 December 2017: 875-883.

[5] Teguh Prihmono, Umar Ma'ruf, and Sri Endah Wahyuningsih. (2017). "Peran Laboratorium Forensik Polri Sebagai Pendukung Penyidikan Secara Ilmiah Dalam Sistem Peradilan Pidana Di Indonesia, Jurnal Hukum Khaira Ummah Vol. 13. No. 1 March 2018: 273-286.

\section{Books:}


[1] Andi Hamzah. (2011). Bunga Rampai Hukum Pidana dan Acara Pidana, Ghalia Indonesia, Jakarta.

[2] Arief, Barda Nawawi. (2011). Masalah Penegakan Hukum dan Kebijakan Penanggulangan Kejahatan, Bandung: PT. Citra Aditya Bakti.

[3] Attamimi, A. Hamid S. (2007). Ilmu Perundang-undangan, Jenis, Fungsi, dan Materi Muatan, Yogyakarta: Kanisius.

[4] Dikoro, Wirjono Prodjo. (2012). Hukum Acara Pidana di Indonesia, Bandung: Sumur Bandung.

[5] Djindang, Moh. Saleh. (2009). Pengantar Hukum Indonesia, Jakarta: Sinar Harapan. 2009.

[6] Halim, Ridwan A. Hukum Pidana dan Tanya Jawab, Jakarta: Ghalia Indonesia.

[7] Harahap, M. Yahya. (2013). Pembahasan Permasalahan dan Penerapan KUHAP: Pemeriksaan Sidang Pengadilan, Banding, Kasasi, dan Peninjauan Kembali, Jakarta: Sinar Grafika.

[8] Ibrahim. (2017). "Penangguhan Penahanan Dalam Proses Perkara Pidana (Studi Kasus Kejaksaan Negeri Palu), Legal Opinion, Palu, ISSN 2527-9505 Vol 3, No 3.

[9] Is, Muhammad Sadi. (2015). Kumpulan Hukum Acara di Indonesia, Jakarta: Prenadamedia Group.

[10] Lamintang, P.A.F. (2016). Dasar-dasar Hukum Pidana Indonesia, Bandung: Sinar Baru.

[11] Marpaung, Leden. (2011). Proses Penanganan Perkara Pidana (Penyelidikan dan Penyidikan), Jakarta: Bina Aksara.

[12] Mien, Rukmini. (2013). Perlindungan HAM melalui Asas Praduga tidak Bersalah dan Asas Persamaan Kedudukan dalam Hukum pada Peradilan Pidana Indonesia, Bandung: PT. Alumni.

[13] Mulyadi, Lilik. (2017). Putusan Hakim Dalam Hukum Acara Pidana: Teori, Praktik, Teknik Penyusunan dan Permasalahannya, Bandung: Citra Aditya Bakti.

[14] Satjipto, Rahardjo. (2002). Polisi Sipil dalam Perubahan Sosial di Indonesia, Jakarta: Kompas. 